\title{
Embodied Disbelief: Poststructural Feminist Atheism
}

\author{
"she must have known that the constancy of God in \\ my life is called by other names, so that I quite \\ rightly pass for an atheist” \\ Jacques Derrida, Circumfession, 155
}

\author{
"Feminist question: \\ Imagine a 'corrected' language. I am against it.” \\ Hélène Cixous, rootprints, 63
}

“[A]re your rights worth nobody liking you? Imfaooooo because your gonna be cranstons biggest douche bag for the next ten years. One day people will randomly say "hey remember that little cunt that tried to take the prayer down." good job, hope the fame was worth it." - Comment from Michael ------- (“Feeling the Christian Love”)

"You're a retard. People in this country have their god given right to worship anyone anything they choose to and who are you to interfere with this. Man you're going to hell. Hey at the end of the day I know it's better to believe in something then nothing at all.. and here you are making yourself more of an outcast and a freak good luck with all that..” - Comment from Owner ("High Schoolers Need Help, Too")

"The cops will not watch you forever... We will get you good.... Maybe you will gangbanged before we throw you out of one of our cars. [sic]" (“Ahlquist Family Told to Get Out”) 
It’s hard not to get angry when you read about Jessica Ahlquist, the 17-year-old high school student who, in April of 2011, became the plaintiff in an ACLU-supported lawsuit against the school district of the City of Cranston in Rhode Island. Ahlquist led a small protest movement in the summer of 2010 against a paper plaque that had been hanging on the wall of the auditorium at Cranston High School West since 1963. The banner was inscribed with the “school prayer,” addressed to "Our Heavenly Father” and closing with "amen,” sandwiching happy secular sentiments about friendship and doing one's best.

From the moment she started her Facebook group, Jessica $<1>$ became the target of an escalating bullying campaign. After the ACLU filed its lawsuit in April, she and her family received death threats, while some students at Cranston started online Facebook groups to attack her. In November 2010, Jessica was escorted from a school committee hearing by police after the audience formed a mob. From that moment on, she would have police protection traveling to and from school.

In January 2012, the day after a District Court judge in Providence ruled for Jessica and the ACLU, a Democratic state representative called her an "evil little thing" in a radio interview. In April of 2012, the Ahlquist family received at their home an unsigned letter, penned by a group of self-described “crusaders” who threaten sexual violence against Jessica and her younger sister and demand the family "get out of Rhode Island."

It's hard not to get angry when you read about Jessica Ahlquist, and how the everyday roiling currents of high school bullying fused with the craven electoral calculus of public and school officials, only to become a national issue launched by the right-wing media apparatus that fuels and feeds on the politics of the tantrum. Headline, Providence Journal, July 20, 2010: 
“ACLU Targets Prayer Banner at High School.” Headline, Fox News, July 23: “ACLU Targets Rhode Island School.”

It’s hard not to get angry when you read about Jessica Ahlquist. At the same time, I, at least, find the content of the lawsuit itself bemusing. The banner is a prayer only to the extent that it opens with "our father” and closes with “amen.” In terms of content it is doctrinally empty and, if the header and footer were removed, it would be indistinguishable from any other annually ignored motivational poster on the wall of a suburban high school. Indeed, Jessica by her own account did not notice the prayer until a friend pointed it out. It was never recited. It was never made a subject of conversation. It was, it seems, as close to harmless as a nominally religious artifact in a public school can be-virtually invisible.

And it's hard not to be frustrated by Jessica and the ACLU—not to mention the atheist guerrillas who dove out of the barracks to back them up. A precocious and extraordinarily selfassertive young woman, who reflects everything that we want in our children, Jessica could be fairly accused of condescension. "It's almost like making a child get a shot even though they don’t want to,” Jessica said in a New York Times interview in January. “It's for their own good. I feel like they might see it as a very negative thing right now, but I'm defending their Constitution, too.” (Goodnough) Jessica’s supporters have their own moments of rhetorical excess to rival Jessica's detractors — though Jessica to her credit does not suffer that vice and will interrupt her more ardent fans mid-diatribe. And even though the school committee bears, in my opinion, full responsibility for incurring $\$ 150,000$ in courtroom fees in choosing to go to war with the ACLU, the perception that the town was being picked on over an insignificant decoration was, in retrospect, inevitable. 
This is by no means to say Jessica and the ACLU were in the wrong. The history of interpretation of the establishment clause of the United States constitution's first amendment makes clear that public buildings may not serve as advertisements for religious organizations or institutions, and there is no doubt that is what this is. The ACLU's victory at the hearing bears out that they and Jessica were on the right side of the law, and the Cranston school committee members patently in the wrong. (Ahlquist v. City of Cranston: 2012) But the case underscores the bizarre torsions that the conversation around atheism takes on as it unfolds in post-secular United States in the $21^{\text {st }}$ century. A school district is required to spend thousands of dollars to destroy a nearly-invisible plaque because it has become overnight a treasured emblem of local identity via a media-aided controversy.

It is precisely in reaction to conversations like this that I believe Jacques Derrida wrote his famous dis-creed, “I quite rightly pass for an atheist.” $(1993,155)$ It captures an ambivalence towards the category of "atheism" illuminated by Ahlquist v. Cranston. Although atheism is a respectable philosophical tradition, the term "atheist" has become radioactive. It reflects not only a label that has been poisoned by negative associations with the sour, incautious work of writers like Christopher Hitchens, Richard Dawkins, and Sam Harris; it is philosophically indebted to an Enlightenment model of subjectivity, in which autonomy is exercised along intersecting tracks of choice, belief, and reason.

Thinkers of the post-secular such as Grace Jantzen (1999), Chris Hedges (2008), and Gavin Hyman (2010) have suggested that atheism is a byproduct of Enlightenment modernism, a positivist formulation that flattens all of religion into a single empirical question: does God exist or not-exist? Jantzen writes that, "both secularism and religion need to be radically rethought as mutually imbricated in some of the most objectionable aspects of the project of modernity." 
(Jantzen: 1999, 8) For these thinkers, this move is deflected by turning to an alternative theism, one that sidesteps the "ontotheological" establishment of God as a "supreme being”-_some sort of chap” in Terry Eagleton's formulation (2006)—by re-envisioning God as the ground of being, or as the horizon of becoming, or as the condition of possibility for all things rather than a being. Jantzen and her cohort thus seek religion by other means, a post-secular theism that keeps the door open for theology, the church, and faith.

These sophisticated philosophical projects are by no means aligned with the anti-atheist reactionaries of Cranston. But a post-secular rebuff of atheism—one that reframes theism as something more noble than the flags of sectarian combat—is not the only response available. Atheism, a principled affirmation of nonbelief —especially in American public spaces where belief is presumed—needs to remain intact as part of the conversation around religion and secularism. Although I'm sympathetic to projects like those of Jantzen and Hyman that seek to renovate theism, the word "God" leaves me unmoved. For me and many others, the conversational starting point can only be atheism, not an avant garde theism.

This paper is a call for a refreshed atheism—a new new atheism that engages the complexity of religious debates without pressing them down into children's jigsaw puzzles. This is where the convergent streams of feminism and poststructuralism enter the picture. My argument is that a feminist, poststructuralist approach can draw out a new paradigm of atheism, one that will begin the slow labor of moving beyond the scuffling stalemate of contemporary debates. This paradigm, embodied disbelief, draws on the feminist tradition's rich array of theorizing around embodiment, and the poststructuralist tradition's deconstruction of the axioms of liberal humanism, the blurring of the autonomous rational subject. Feminism and poststructuralism here are not so much firm disciplinary labels as intellectual styles, ways of 
viewing the conversation around atheism that can help us make sense of Derrida's cryptic contribution: "I quite rightly pass...” In keeping with this, embodied disbelief is also best understood as a style, a set of conversational practices, rather than an immovable intellectual fortress.

Existing feminist approaches to atheism tend to focus on the oppression of women at the hands of extremist visions of religion. Beginning with early feminist figures such as Elizabeth Cady Stanton and Emma Goldman and extending to the present day with Ayaan Hirsi Ali (2008), these feminists might be classified as what Magda Michielsens (2009) terms "militant atheist feminism.” Mutatis mutandis, these feminists rehearse liberal, Marxist, and humanist arguments against religion’s oppressive effects, with a particular focus on the marginalization and domination of women. Like the New Atheists, with whom Ali is affiliated, this brand of feminist atheism takes an abolitionist approach to religion. Weaving together social critique and Enlightenment attacks on religion as a set of false "hypotheses," militant atheist feminism argues for a decisive break with religion—an obliteration—driven by the machines of reason or progress.

Another feminist approach might ask how this particular female body's atheism became a problem in this place and time. In what way was the response to Jessica's atheism gendered? Were the attacks on Jessica from the other members of her school and community more severe because she is female? Did her gender play a role in how other bodies-especially male bodies—rushed to defend her? Would state representative Palumbo refer to a teenage boy as an "evil little thing”? If women are seen as the repositories of tradition, is a female body turning against tradition a special problem? Would a male student have been victimized with the same 
threats of sexual violence? Or would he have suffered actual violence, which, to my knowledge, Jessica Ahlquist has not? These are all productive lines of inquiry for a feminist analysis.

This paper will take a different approach, examining three domains of feminist scholarship that I think are particularly interesting in dialogue with poststructuralism: epistemology, relationality, and affect. Exploring these areas opens up new strategies for feminist conversations about religion and atheism, a paradigm of embodied disbelief.

\section{Epistemology}

Feminist epistemology rejects the division of the world into knowing subjects and calculable objects, inculcating an epistemic humility that calls into question assertions of foundational certainty on methodological grounds. Feminist epistemology begins with studies conducted in the 1980s by Genevieve Lloyd (1993), Susan Bordo (1987), and Alison Jaggar (1989) on the conceptual linkage of reason and masculinity over and against embodiment and femininity in the Western tradition. But as Linda Martín Alcoff and Elizabeth Potter (1993) suggest, feminist epistemology is not just about gender, but the way that embodied power relations are embedded in the production of knowledge. (3) Feminist epistemology assumes a broad scope to rethink the western epistemological tradition.

In the introduction to their 1989 anthology Gender/Body/Knowledge: Feminist Reconstructions of Being and Knowing, Jaggar and Bordo lay out six foundational assumptions of what they term Cartesian epistemology—the formula characterizing Descartes and his successors: First, metaphysical realism, the independence of objective reality from human understanding; Objectivism, the accessibility of nature/reality to human understanding; epistemological individualism, the notion that knowledge is best built up by individuals; 
rationalism and empiricism as our best avenues for acquiring knowledge; universalism, that all individuals have identical access to knowledge; and foundationalism, that knowledge is constructed out of indubitable epistemological units very finely broken down. (Jaggar \& Bordo: 1989, 3)

Lorraine Code (1993) has suggested that the sum total of these different epistemological components is a picture of knowledge as produced by detachment. Rather than a perspectivally constituted knowledge, the Cartesian approach affords a "view from nowhere" in which abstract knowledge of the world floats above the world. In Code's account, this model diminishes epistemological competence by degrading the ability to track how the production of knowledge shapes the forms of knowledge produced - the mechanism of correction that is at the crux of academic inquiry. Against this image of epistemological autonomy, feminist epistemologists put forward a different kind of knower, what Jaggar and Bordo describe as "a historically particular individual who is social, embodied, interested, emotional, and rational and whose body, interests, emotions, and reason are fundamentally constituted by her particular historical context.” (1989, 6) What feminist epistemology fundamentally overturns, writes Jaggar (1989), is "the myth of dispassionate investigation.” (155)

Contemporary feminist epistemology has advanced in part through the development of what Susan Hekman and Stacey Alaimo (2008) have called “material feminisms,” new approaches that thematize how pre-discursive material forces, particularly bodies, inform the production of knowledge. Karen Barad (2008) proposes a "posthumanist performativity" as a corrective to the overreliance on language in epistemology. "Performativity, properly construed," she writes, "is not an invitation to turn everything (including material bodies) into words; on the contrary, performativity is precisely a contestation of the excessive power granted 
to language to determine what is real.” (121) Barad condenses the earlier feminist formulation of opposition to Cartesianism into a critique of liberal representationalist models, which she defines as "the belief in the ontological distinction between representations and what they purport to represent... that which is represented is held to be independent of all practices of representing."

Against this dualism of representations and things to be represented, Barad uses performativity theory to develop a posthumanist epistemology in which representations themselves are seen as among the field of epistemic agents. (126) Words are not neutral mediators between objects and meanings, the finely granulated material out of which knowledge is fashioned; they make knowledge production possible by injecting their own chunky materiality into the matrix of the epistemological field. Neither pristinely neutral nor overridingly determinative, words feed into the "specific material (re)configuring of the world through which local determinations of boundaries, properties, and meanings are differentially enacted.” (138) More than an epistemology, Barad suggests a shift to an onto-epistemologyviewing discourse as an actant in the production of knowledge.

In Elizabeth Grosz’s (1993) hands, this material feminist epistemology suggests the intersection of material words with knowing bodies in such a way as to configure how bodies know things. “Clothing, jewelry, makeup, cars, living spaces, and work,” she writes, “all function to mark the subject's body as deeply as any physical incision, binding individuals to systems of significance in which they become signs to be read (by others and themselves).” (199) Not only linguistic but cultural and practical forms condition bodies, the things that know. Knowledge emerges out of these nodal particularities, not in an abstract universal space. 
What are the implications of feminist epistemology, then, for an embodied disbelief? On one level, feminist epistemology is a sinuous and compelling call for epistemological humility, a recognition of how knowledge is constituted through embodied circumstances. As Jantzen has pointed out, "religious discourse in modernity is, together with science and economics and law, part of a grand myth of rationality,” $(1999,22)$ an overweening confidence in the power of reason to sort everything out. Contemporary atheism tends to traffic in certainties: there is a sneering and inflexible dismissal of, for instance, the term "agnostic," with Richard Dawkins (2008) chuckling that "I am agnostic only to the extent that I am agnostic about fairies at the bottom of the garden." (74) No-one could accuse Dawkins or his fellow "Four Horsemen," <2> of epistemic humility. Feminist epistemology is a corrective to that overconfidence, compelling a willingness to enter into conversations armed with an understanding embedded in a particularity—not a proof. This is John D. Caputo's reading of Derrida's “Circumfession,” in which deconstruction has a distinctly feminist sensibility, representing "the unveiling of the bad news that nobody has a revelation, that we are all in this together and that nobody has won the high ground of the grand seigneur.” $(1997,71)$

On another level, though, there is a deeper argument at work here. Grosz writes that "[f]ood, dieting, exercise, and movement provide meanings, values, norms, and ideals that the subject actively ingests, incorporating social categories into the physiological interior.” (1993, 199) What if the words, the habits, the relationships, and the affects that orbit religion were part of this regime of ingestion—a diet—and were the ingredients of a particular knowing subject? I said earlier that the word "God" leaves me unmoved. But I have noticed that my colleagues in the academy often have a different reaction. $<3>$ Our particular embodied discourses always seem to have a god term, a word or cluster of words that have an overflow of affective and 
semantic meaning, serving as a nexus point for channels of significance, magnetizing an entire philosophical apparatus. For some bodies, for some discourses, this god-term is "God.” (cf. Caputo: 1997, 68) These are systems of knowledge-production that have been organized around a religious vocabulary and suffer no loss of sophistication for it. Poststructural feminist atheism is about finding constructive ways to engage with alternate epistemological vocabularieswithout feeling the need to dominate, eliminate, or clarify them according to an atheist logic.

\section{Relationality}

As Code writes, the epistemology of detachment has been "constructed through processes of excluding the attributes and experiences commonly associated with femaleness and underclass social status: emotion, connection, practicality, sensitivity, and idiosyncracy.” [sic] $(1993,21)$ In the last two sections of this paper, I outline the roles of relationality and emotionality in embodied disbelief.

The feminist emphasis on relationality helps us to redefine atheism not as a radical conceptual break, but as an intellectual movement within and sustained by a larger conversational field. I am sensitive to Joan Tronto's (1989) critique of the cultural feminism movement of the late 1970s and early 1980s, which made the "feminine" trait of "caring" into a feminist maxim; she calls for us to "be careful” in normalizing "care.” (172) But a poststructural feminism is interested in exploring the ways that the purported autonomy of free, knowing subjects disguises relational, interconnected bodies. Rather than viewing atheism as militant, poststructural feminist atheism poses non-belief as a contingent positionality that remains in relationship with other bodies—bodies with other values and other beliefs. 
The emphasis on relationality need not come out of cultural feminism. It draws on a much stronger taproot in French feminism, which poses questions of gender difference and embodied practice with nuance. Julia Kristeva in Tales of Love (trans. 1987), while acknowledging the possibility that "love” calls up a heterogeneous array of possible meanings (2), nonetheless defines love, relationality in its highest form, as the zone of risk, "a state of instability in which the individual is no longer indivisible and allows himself to become lost in the other, for the other. Within love, a risk that might otherwise be tragic is accepted, normalized, made fully reassuring.” (4) For Kristeva, the practice of love is not marked by ease, but by a potentially troubling and unsettling committed encounter with another body.

Hélène Cixous corroborates this sense of love as an encounter with alterity. Returning to the epigraph of this paper:

"Still this problem of the law and the language.

Feminist question:

Imagine a 'corrected' language. I am against it.

The grammatical effects are precious. Indeed, they allow us to play. We would not play any more;

We would not shift things around any more.

The fact that language resists me, hampers me, is a good thing. There is a profit. And what to do with the word philosopher? How to 'correct' it?

I could no longer play at the moone and the other [la lune et l'autre].” (Cixous and CalleGruber: 1997, 63) 
In Cixous's onto-epistemology, the intransigent complexity of language mirrors the irreducible intransigence of the other, the impossibility of assimilating the other to the same. Other bodies, like language, are incorrigible. They cannot be commoditized, flattened, disintegrated. But this incorrigibility is the texture of the relational field. In a section entitled "less self," Cixous writes that in order to achieve love "One must open oneself, one must make room for the other." (Cixous and Calle-Gruber: 1997, 110) And this self-displacement is also a desire, a craving to know the passions of the other. (Cixous \& Calle-Gruber: 1997 55) Cixous and Kristeva make relationality into a challenge, a source of productive friction for the self, not a consumption of the other through an undertheorized act of "care."

An invaluable theoretical scaffolding for this riff on love is found in Donna Haraway's material feminist ontology, particularly in her Companion Species Manifesto (2003). Following Whitehead, Haraway suggests that beings are constituted by prehensions—graspings, touchings, relationships with other beings. "There are no pre-constituted subjects and objects," she writes, “and no single sources, unitary actors, or final ends." (6) Instead, building on her earlier work on cyborg ontology, she proposes an ethics of companion species, "in which co-constitution, finitude, impurity, historicity, and complexity are what is.” (16) Rather than seeing ethical behavior as beginning in the agency of autonomous actors, Haraway reframes ethics as set against the backdrop of a constant flush of interrelating bodies.

For Haraway, "all ethical relating, within or between species, is knit from the silk-strong thread of ongoing alertness to otherness-in-relation.” (50) Ethics is not, therefore, about the transaction between sames: it requires an attention to the other body in its alterity, a holistic prehension of that species and the conditions of their flourishing. Haraway, writing about dogs rather than gods, affirms that "to be in connection with significant otherness and signifying 
others, on many scales” requires "know[ing] how to live with the histories I am coming to know.” (81) Relationality, for Haraway, means finding ways to meaningfully encounter the ethical other in its historical particularity. How can we engage these bodies, these histories?

The notion of relationality as at once an ontological inevitability, a desire, and a challenge has marked implications for the development of embodied disbelief. Feminist atheist Ursula K. LeGuin, in her 1986 Bryn Mawr Commencement Address, draws this out by elaborating on the difference between the mother tongue and the father tongue. The father tongue, she explains, is the "language of power_of social power," a language that gets people to do things. $(1989,147)$ LeGuin does not dismiss the father tongue, which she calls "an excellent dialect” (148), one that produces knowledge by dividing the subject from the world. But she is wary of the way that the father tongue lapses into a logic of command that is presupposed to be the only dialect, the only way to talk.

The mother tongue, by contrast, which LeGuin tells the women of Bryn Mawr is a language learned by “you and your brothers,” (149) is the common tongue, the vulgate, the vernacular. "The mother tongue,” she says,

“spoken or written, expects an answer.... The mother tongue is language not as mere communication but as relation, relationship. It connects. It goes two ways, many ways, an exchange, a network.” (149)

Where the father tongue "only lectures" (147) the mother tongue is the animating force of conversation, a style of speech that prompts responses. It is a language of shared textures, openings, and exchanges. 
There is an important procedural ramification that follows from this insight: a framing of atheism not as a programmatic conflict—as a declaration of war—but as a transaction. Rather than a rupture, a rejection and supersession of a theistic cultural inheritance, poststructural feminist atheism is a new set of relational practices that emerge in a living conversation between believers and nonbelievers. The starting point of embodied disbelief is not the paramount virtue of winning arguments: it is first and foremost about maintaining relationships, about honoring the difficulty of remaining in contact with friends, family, and community members who start with a different set of intellectual coordinates. Whereas many atheists start from the battle line that religion has "on balance" been "bad for" the world, $<4>$ the eliminativist stance, poststructural feminist atheism always asks itself before it goes to war: is winning theological fights the most important part of our work?

Thus, Derrida writes of how his mother "asked other people a while ago, not daring to talk to me about it, if I still believed in God” (155). Derrida's intuition, the germ of the anticreed "I quite rightly pass...," is that his filiation, his connection to his mother's deepest hopes and desires for him, is simultaneously inalienable and constitutively alien to his intellectual trajectory—indeed to the deepest sentiments constituting his self. Derrida's writings on God are a way of letting his mother in, of maintaining a connection, of opening a border to traffic rather than militarizing it. $<5>$

At the same time, the emphasis on relationality helps us understand the deadly toxicity of anti-atheist discourse. Dawkins returns periodically to a memorable line from Julia Sweeney's Letting Go of God show: "I think that my parents had been mildly disappointed when I'd said I didn't believe in God any more, but being an atheist was another thing altogether.” $(2008,365)$ Sweeney's case is not uncommon. In the United States, in particular, there is a spit-reaction that 
many have to the term "atheist.” It is a word that people like to spit on. This is important for understanding Jessica's own position in Cranston, the feeling of isolation she must have felt as the atheist in suburban Cranston—_that girl," "that little witch.” And Jessica writes articulately about hiding, about the need for a supportive community, and the warmth of feeling a community coalescing around her—especially online—as her notoriety increased. (“A Quick History”)

Poststructural feminist atheism, then, starts from the presupposition that bodies are always already in connection, emerge as members of a community rather than as autonomous agents. The embodied need for community, the paramount importance of connection, is a double-faced critique that addresses both the discursive practices of atheism and the accusers of atheism.

\section{Affect}

The mother tongue, LeGuin writes, “is a language always on the verge of silence and often on the verge of song. It is the language stories are told in.” $(1989,150)$ Feminist epistemology, going back to Code, is also about how emotion serves as a register of knowing. Hence the longstanding interest among feminist theorists in affect. $<6>$ What Patricia Clough (2010) has called the "turn to affect" in feminist and queer theory helps us understand the impulses that surround atheism. $<7>$

Jaggar writes that emotion in the western tradition is lined up with "the irrational, the physical, the natural, the particular, the private, and, of course, the female.” $(1989,145)$ The erasure of the affective is one of the founding gestures of Cartesian epistemology, but Jaggar shows that emotion is actually crucial to the process of knowledge production. Emotion, she 
suggests, is the material comprising our interest: "the individual experience of emotion focuses our attention selectively, directing, shaping, and even partially defining our observations, just as our observations direct, shape, and partially define our emotions.” $(1989,154)$

This interest in how affect shapes even purportedly affect-neutral enterprises like scientific and philosophical inquiry is a guiding principle of contemporary affect theory. Although some varieties of affect theory promoted by scholars such as Clough (2010 and see endnote $<7>$, below), Brian Massumi (2002) and William Connolly (2011) strictly differentiate affect from felt emotion, I want to turn to those more closely allied with feminism. Eve Kosofsky Sedgwick (2003), for instance, sees affect as a vein of performativity theory that "address[es] aspects of experience and reality that do not present themselves in propositional or even in verbal form alongside others that do.” (6) The upshot of this is a new emphasis on phenomenology, asking questions about "what motivates performativity and performance, for example, and what individual and collective effects are mobilized in their execution?” (17)

For Sedgwick, following the work of Silvan Tomkins (2008), affect, unlike the Freudian register of drives, can be invested in any object at all: "things, people, ideas, sensations, relations, activities, ambitions, institutions, and any number of other things, including other affects." (19) She finds in Tomkins a point of commonality with what I'm here identifying as feminist epistemology, the placement of cognitive interest within an affective framework-the polarity of shame-interest. (97) The corollary inquiry, for Sedgwick, is the question of how knowledge itself is performative, how it sets the stage for the drama of embodied affects: "What does knowledge $d o$ - the pursuit of it, the having and exposing of it, the receiving again of knowledge of what one already knows?” (124) Or, put another way, why do we think what we think? How does affect inform what we believe or disbelieve? 
The affective approach dovetails well with Jantzen's feminist deconstruction of AngloAmerican philosophy of religion. Jantzen's approach highlights how desire is present even in creedal proposition. $(1999,77)$ “Without the intense desire to be rational,” Jantzen argues, “and indeed to construe rationality along the lines of justified beliefs about which one can formulate belief policies which in turn preserve and defend such rationality, the whole enterprise could not get started.” (1999, 84) From the other direction, Caputo suggests that a faith informed by deconstruction is itself an exercise of passion. "Deconstruction," he writes, "is trying to inflame the passion of faith, to incite a riot, to drive us mad with passion, not to neutralize exciting and inflaming discourses.” $(1997,59)$ Both of these approaches highlight the affectivity of discourse, what Ahmed (2004c) calls "the emotionality of texts.” (13)

How does affect theory interface with atheism? Ahmed has written in her 2004 essay “Affective Economies” that emotions "play a crucial role in the 'surfacing' of individual and collective bodies through the way in which emotions circulate between bodies and signs.” (2004a, 117) In other words, emotions are the mechanism by which the sensitive skin of an "us" is produced; they "align individuals with communities—or bodily space with social space— through the very intensity of their attachments." (2004a, 119) Emotions, reeling off from signs, are integral to the fortification of an us/them divide.

The method of poststructural feminist atheism, then, is vigilance towards the way that the conversation between atheism and theism is shaped by affective forces. Religion scholar Stephen Prothero (2010) has suggested a typological distinction between "angry atheists" and "friendly atheists," with the latter inhabiting a "Manichean world" and at constant risk of inadvertently establishing a "religion of sorts" marked by zeal, evangelism, and the worship of “reason.” (318) The New Atheists are textbook examples of this, exhibiting an acerbic disdain 
towards religious believers. Dawkins, for instance, in the preface to the 2008 edition of The God Delusion, suggests that bad reviews of his book have come primarily from "faith-heads" and reaffirms his claim that " $[\mathrm{t}] \mathrm{o}$ the vast majority of believers around the world, religion all too closely resembles what you hear from the likes of Robertson, Falwell, or Haggard, Osama bin Laden or the Ayatollah Khomeini.” (15) Chris Hedges (2008) has argued that the New Atheists are of the "world of entertainment.... They appeal to our deepest and most irrational subliminal desires.” (178) Indeed, following Ahmed, the idea that a self-serving atheism exercises anger in order to manifest surfacing affects seems difficult to contest as one wanders through the pyrotechnic displays, mordant wit, and carnivalesque rants of the New Atheist canon.

This anger is matched by the intensity of emotion found across the river. Jessica Ahlquist, for instance, describes the school subcommittee meeting where she presented her case like this:

"At the first meeting, I spoke in front of the sub-committee and about ten or fifteen residents. I presented myself as an atheist, aware that the word was taboo, but unaware of just how much. When I said this, I heard a small gasp along with a bit of whispering. As I sat down after speaking, one of the accepting, non-judgmental Christians in the room mumbled "that little witch!” under her breath.” (Quick History)

This, as we have seen, was only the beginning. Death and rape threats made against Jessica and her family continue.

LeGuin identifies the same phenomenon in her review of C.S. Lewis's The Dark Tower. She attacks Lewis's misogynistic portrayals of women as well as the way that Christianity in his 
work becomes a sort of "exclusive club, those who know inside, the heathens in the outer dark." $(1989,242)$ “There’s a great deal of hatred in Lewis,” she muses. $(1989,243)$ And whereas in Tolkien she finds a conscientious lack of hatred—no-one who has read the trilogy hates Gollum, she points out-

"[i]n Lewis, responsibility appears only in the form of the Christian hero fighting and defeating the enemy: a triumph, not of love, but of hatred. The enemy is not oneself but the Wholly Other, demoniac. This projection leaves the author free to be cruel.” (LeGuin: 1989, 244)

There's a savoring of the persecution of atheists in the background of these discourses, a fantasy of Dark Ages retribution. What I think poststructural feminist atheism helps us delineate is the way that this dynamic of rage mutually reinforces and hardens the aggressive posturing on both sides, and how eventually that posturing becomes the conversation.

This is a call for sympathy, not a critique. I would wager that Dawkins, since publishing The Selfish Gene in 1976, with its likening of "the God meme” to a parasitic virus (207; cf. Dennett: 2006, Introduction), has received more unhinged and violent hate mail than any academic in history. How has that current of invective shaped the way he thinks, the way he feels, the way he works, the ways he promotes and defends his ideas? A feminist approach tries to bring these acidic streams to the surface, to feel around for where the scar tissues and the open wounds beneath our feet might trip us up. Embodied disbelief wants to drag the conversation out of the war zone.

\section{Conclusion}


Traditional and New Atheisms tend to represent themselves as the triumph of reason, the final correction of the last bastion of ignorance, religion, a cognitive calculus untouched by bodies or emotion. This framing is not only an attempt to replicate positivist scientific epistemologies: it masks the affective processes that motivate atheism as a set of embodied practices.

Poststructural feminist atheism takes seriously the embodiment of belief and disbelief. This entails not only a radical commitment to material bodies as the only possible origin of religion, but a suspicion towards forms of atheism that insist on a relationship between bodies and religion organized according to abstract reason. By calling attention to epistemology, relationality, and affect, poststructural feminism shows that religion and anti-religion are fused in a close-knit dance. Rather than seeking to purify us of religion, poststructural feminist atheism calls on us to understand religion and non-religion emerging as products of our living embodied experience, as accidents of animal life.

Embodied disbelief is not, therefore, a standing academic position. It is a technique, a sensitivity, a way of paying attention. It is a process designed to completely transform the conversational landscape on which the debates around atheism and theism take place. No longer an abstract grid arranged along the axes of putatively disinterested logic, embodied disbelief finds these conversations emerging from interested, partial bodies, bodies with histories that shape their vocabularies, their rationality, and their criteria of meaning. "Bodies speak," writes Grosz (1993, 199). Embodied disbelief attunes itself to these frequencies outside the narrow band of abstract logic.

No longer a battlefield, a war zone ruled by high stakes and thundering urgency, embodied disbelief traces instead a living tissue of relationships. It presumes that conversations 
about God happen between bodies that are always already connected, and it takes seriously the intrinsic value of those connections. Haraway, with trademark eloquence, articulates the necessity of a style of connection that expects and respects connections to form between nonhomogeneous bodies:

“Answers to these questions can only be put together in emergent practices; i.e., in vulnerable, on-the-ground work that cobbles together non-harmonious agencies and ways of living that are accountable both to their disparate inherited histories and to their barely possible but absolutely necessary joint futures. For me, that is what significant otherness signifies.” (2003, 7, italics original)

And no longer a colorless moonscape, embodied atheism is acutely attentive to the affective valences of conversation itself. It sees how the currents of affect, the reds and the blues, paint books and bodies. It sees how they layer to form the thrilling, tense, swirls of identity, and how those swirls harden into addictions, warping and distorting the possibility of movement. This vision may mean taking a less cavalier attitude about turning something that brings us joy or comfort — like a prayer mural in a staunchly Catholic suburb-into something that makes us ashamed. It certainly means being sensitive to the ways that a brilliant young woman can shame a community into a churlish response-and how that shame throws a thoughtful détente far into the distance. And it means being aware of the ways that the epic narrative of atheism's own self-understanding becomes addictive- - the surging pride and selfimportance of the fight against injustice, the anger — and how those emotions can make atheists 
themselves condescending and bitter. Embodied disbelief always holds itself in suspicion to keep these tendencies at bay.

Embodied disbelief is necessary, not only to understand the post-secular landscape, but to meaningfully intervene within it. Exemplars of this method are rare in popular culture-they don't sell books as well as their more apocalyptic atheist brethren—but consider the former humanist chaplain at Harvard, Chris Stedman, an openly gay, atheist, interfaith activist, who refuses to let his commitment to atheism interfere with his work-the construction of relationships between religious and non-religious bodies. "Directing anger at others can feel good,” Stedman writes, "but I’ve found that a hangover follows.” (Stedman: 2012, 160) It's hard not to get angry, and when high school bullying is given a national platform to start attacking children, the time for anger may have come—but Stedman is a guiding light in finding ways to do more than just get angry. "We can be dogmatically fixated on who is 'right' and who is 'wrong,"” he concludes, "or we can discern a way to live together in tension and ambiguity.” (Stedman: 2012, 180)

“Are your rights worth nobody liking you?” writes Michael, a bully sneering at a 16year-old girl on her Facebook page. The paradigm of embodied disbelief makes this a real question, and doesn't make the answer any easier. Poststructural feminist atheism deepens the tensions at the heart of modern liberalism—-the unresolved remainders jutting out between our liberal amalgam of ideas, words, bodies, rights, freedom, and community —and brings them to the surface without claiming to have a monopoly on their resolution. What this method does do is help us map out the landscape of situations like Jessica's more clearly, color-staining the thick junctures between bodies, discourses, affects, and seams of power. And in the process, it marks 
the way forward, the slow path of transformational dialogue, the incremental realignment of all our embodied beliefs and disbeliefs. 
Notes

Acknowledgments

My deepest thanks to Mariam Parekh and Brad Swain for lengthy conversations at crucial junctures in the writing of this piece. My special thinks to the anonymous reviewers at Hypatia for thoughtful comments that substantially improved my argument and writing. Thanks to the organizers of the "Varieties of Continental Thought in Religion” conference at Ryerson University in June 2012, John Caruana and Mark Cauchi, for providing a forum for this work, and the audience at the conference who provided valuable feedback, in particular Jack Caputo, Morny Joy, Allison Covey, Deborah Bowen, Brian Rogers, Muhammad Velji, and John Caruana.

$<1>$ I here use the journalistic convention of referring to minors by first name. It is easy to forget that although Jessica exhibits extraordinary poise, she is far younger than most of the men and women who have lined up to denounce her in public.

$<2>$ See Dawkins et al., 2008.

$<3>$ Jantzen is an excellent example of this. Kevin Hart is another, with his famous response to Derrida that "I quite rightly pass for a believer.” $(2001,193)$

$<4>$ See, for instance, Dawkins: 2008, Chapter 8. 
$<5>$ Caputo makes a parallel point in an essay on the differences between Derrida and Heidegger's readings of Augustine. For Heidegger, Monica is categorically erased from Augustine’s narrative; for Derrida, she is central. Caputo suggests that this omission on Heidegger's part enables the chauvinistic, militarized hermeneutic that he brings to Augustine, the model “Christian soldier.” (2001, 152) Derrida, by contrast, identifies with Augustine’s tears - the binding agent that links Augustine, in grief, to his mother, and Derrida to his own mother, Georgette Safar Derrida. In the process, this tearfulness, in Caputo’s reading, is a betrayal of the masculinist imperative built into Heidegger, a renunciation of the disconnected "knight of anticipatory resoluteness, ready for anxiety, a macho, virile figure out there all alone” (2001, 159).

<6> See Ahmed 2004c, “Introduction: Feel Your Way” for a well-put-together review of the literature.

$<7>$ That said, Clough also wants the affective turn to abjure analyses that focus on "the felt affects” (207) — which she sees as a retrieval of the subjective mode that affect theory overturns. Without getting into the particulars of this debate within affect theory, I am here going to take a different tack, following Ahmed's focus on "the lived experiences of being and having a body." (Ahmed: 2004b, 39, en. 4) 
References

Ahlquist, Jessica. 2011. A quick history. http://jessicaahlquist.com/2011/05/a-quick-history/ (accessed June 20, 2012)

Ahlquist, Jessica. 2011. Christian love. http://jessicaahlquist.com/christian-love/ (accessed June 20, 2012)

Ahlquist, Jessica. 2011. High schoolers need *help* too.

http://jessicaahlquist.com/2011/07/high-schoolers-need-help-too/ (accessed June 20, 2012)

Ahlquist v. City of Cranston, Dist. Court, D. Rhode Island. 2012. C.A. No. 11-138L.

Ahmed, Sara. “Affective Economies.” Social Text 79, Vol. 22, No. 2, Summer 2004a: 117-139.

Ahmed, Sara. “Collective Feelings, Or, The Impressions Left by Others.” Theory, Culture \& Society 2004b. Vol. 21(2): 25-42.

Ahmed, Sara. The Cultural Politics of Emotion. New York: Routledge, 2004c.

Alaimo, Stacy, and Susan Hekman. "Introduction: Emerging Models of Materiality in Feminist Theory.” In: Alaimo, Stacy, and Susan Hekman, eds. Material Feminisms. Bloomington and Indianapolis: Indiana University Press, 2008: 1-19. 
Ali, Ayaan Hirsi. 2008. Infidel. New York: Free Press.

Arditi, Lynn. Cranston West prayer banner was removed Saturday, school chief says. The

Providence Journal. March 3, 2012. http://news.providencejournal.com/breakingnews/2012/03/cranston-west-p-1.html

Armental, Maria. Cranston police investigate threats to student who sued over Cranston West prayer banner. The Providence Journal. April 12, 2012.

http://news.providencejournal.com/breaking-news/2012/04/cranston-police-31.html

Barad, Karen. "Posthumanist Performativity: Toward an Understanding of How Matter Comes to Matter.” In: Alaimo, Stacy, and Susan Hekman, eds. Material Feminisms. Bloomington and Indianapolis: Indiana University Press, 2008: 120-154.

Alcoff, Linda Martìn, and Elizabeth Potter. "Introduction: When Feminisms Intersect Epistemology.” In: Feminist Epistemologies. Alcoff, Linda Martìn, and Elizabeth Potter, eds. New York: Routledge, 1993: 1-14.

Bordo, Susan. The Flight to Objectivity: Essays on Cartesianism and Culture. Albany: SUNY press, 1987.

Caputo, John D. The Prayers and Tears of Jacques Derrida: Religion without Religion. Bloomington and Indianapolis: Indiana University Press, 1997. 
Caputo, John D. 2001. The absence of Monica: Heidegger, Derrida, and Augustine’s

Confessions. In: Holland, Nancy J., and Patricia Huntington, eds. Feminist interpretations of Martin Heidegger. University Park: Pennsylvania State University Press: 149-164.

Cixous, Hélène and Mireille Calle-Gruber. rootprints: Memory and Life Writing. Trans. Eric Prenowitz. London and NY: Routledge, 1997.

Clough, Patricia. “The Affective Turn: Political Economy, Biomedia, and Bodies.” In: Gregg, Melissa, and Gregory J. Seigworth, eds. The Affect Theory Reader. Durham, NC, and London: Duke University Press, 2010: 206-225.

Code, Lorraine. “Taking Subjectivity into Account.” In: Feminist Epistemologies. Alcoff, Linda Martin, and Elizabeth Potter, eds. New York: Routledge, 1993: 15-48.

Connolly, William. 2011. A world of becoming. Durham, NC: Duke University Press.

Derrida, Jacques. 1993. Circumfession: fifty-nine periods and periprhrases. In: Bennington, Geoffrey and Jacques Derrida. Jacques Derrida. Chicago: University of Chicago Press.

Dawkins, Richard. The God Delusion. New York: Mariner Books, 2008.

Dawkins, Richard. 1976. The Selfish Gene. Oxford and New York: Oxford University Press. 
Dawkins, Richard, Daniel C. Dennett, Sam Harris, Christopher Hitchens. The Four Horsemen. http://www.youtube.com/watch?v=9DKhc1pcDFM and http://www.youtube.com/watch?v=TaeJf-Yia3A\&feature=relmfu (accessed June 20, 2012)

Dennett, Daniel C. Breaking the Spell: Religion as a Natural Phenomenon. New York, etc.: Penguin Books, 2006.

Eagleton, Terry. “Lunging, Flailing, Mispunching.” A review of Richard Dawkins' The God Delusion. London Review of Books: October 19, 2006. Available at: http://www.lrb.co.uk/v28/n20/terry-eagleton/lunging-flailing-mispunching Accessed June 20, 2012.

Goodnough, Abby. Student faces town's wrath in protest against a prayer. The New York Times. January 26, 2012. Available at: http://www.nytimes.com/2012/01/27/us/rhode-island-cityenraged-over-school-prayer-lawsuit.html

Grosz, Elizabeth. "Bodies and Knowledges: Feminism and the Crisis of Reason.” In: Feminist Epistemologies. Alcoff, Linda Martin, and Elizabeth Potter, eds. New York: Routledge, 1993: 187-215.

Haraway, Donna. The Companion Species Manifesto. Chicago: Prickly Paradigm Press, 2003. 
Hart, Kevin. 2001. Absolute interruption. In: Caputo, John D., Mark Dooley, and Michael J. Scanlon, eds. Questioning God. Bloomington, IN: Indiana University Press: 186-208.

Hedges, Chris. I Don't Believe in Atheists. New York: Free Press, 2008.

Hyman, Gavin. 2010. A short history of atheism. London and New York: I.B. Tauris Press.

Jaggar, Alison M. and Susan R. Bordo. “Introduction.” In: Jaggar, Alison M. and Susan R. Bordo, eds. Gender/Body/Knowledge: Feminist Reconstructions of Being and Knowing. New Brunswick, NJ, and London: Rutgers University Press, 1989: 1-10.

Jaggar, Alison M. “Love and Knowledge: Emotion in Feminist Epistemology.” In: Jaggar, Alison M. and Susan R. Bordo, eds. Gender/Body/Knowledge: Feminist Reconstructions of Being and Knowing. New Brunswick, NJ, and London: Rutgers University Press, 1989: 145171.

Jantzen, Grace M. Becoming Divine: Towards a Feminist Philosophy of Religion. Bloomington and Indianapolis: Indiana University Press, 1999.

Kristeva, Julia. Tales of Love. Trans. Leon S. Roudiez. New York: Columbia, 1987.

LeGuin, Ursula K. The Left Hand of Darkness. New York, etc.: Harper and Row, 1980. 
LeGuin, Ursula K. Dancing on the Edge of the World: Thoughts on Words, Women, Places. New York: Grove, 1989.

Lloyd, Genevieve. The Man of Reason: 'Male' and 'Female' in Western Philosophy. Second edition. Minneapolis: University of Minnesota Press, 1993.

Massumi, Brian. Parables for the Virtual: Movement, Affect, Sensation. Durham, NC, and London: Duke University Press, 2002.

Michielsens, Magda. 2009. Gender and humanism. Talk delivered at European Humanist Professionals Conference, Berlin. Available at http://www.moh.be/publications_magda_michielsens.htm (accessed June 20, 2012)

Prothero, Stephen. God is Not One: The Eight Rival Religions that Run the World—And Why their Differences Matter. New York: HarperOne, 2010.

Rollins, Peter. "Why the New Atheists Don't Go Far Enough.” Talk delivered at Revolution NYC in Brooklyn, NY, October 10, 2010.

Sedgwick, Eve Kosofsky. Touching Feeling: Affect, Pedagogy, Performativity. Durham and London: Duke University Press, 2003.

Stedman, Chris. Faitheist: How an Atheist Found Common Ground with the Religious. Boston, 
MA: Beacon Press, 2012.

Tomkins, Silvan S. Affect Imagery Consciousness: The Complete Edition. Bertram P. Karon, ed. New York: Springer Publishing Company, 2008.

Tronto, Joan C. "Women and Caring: What Can Feminists Learn about Morality from Caring.” In: Jaggar, Alison M. and Susan R. Bordo, eds. Gender/Body/Knowledge: Feminist Reconstructions of Being and Knowing. New Brunswick, NJ, and London: Rutgers University Press, 1989: 172-187. 